
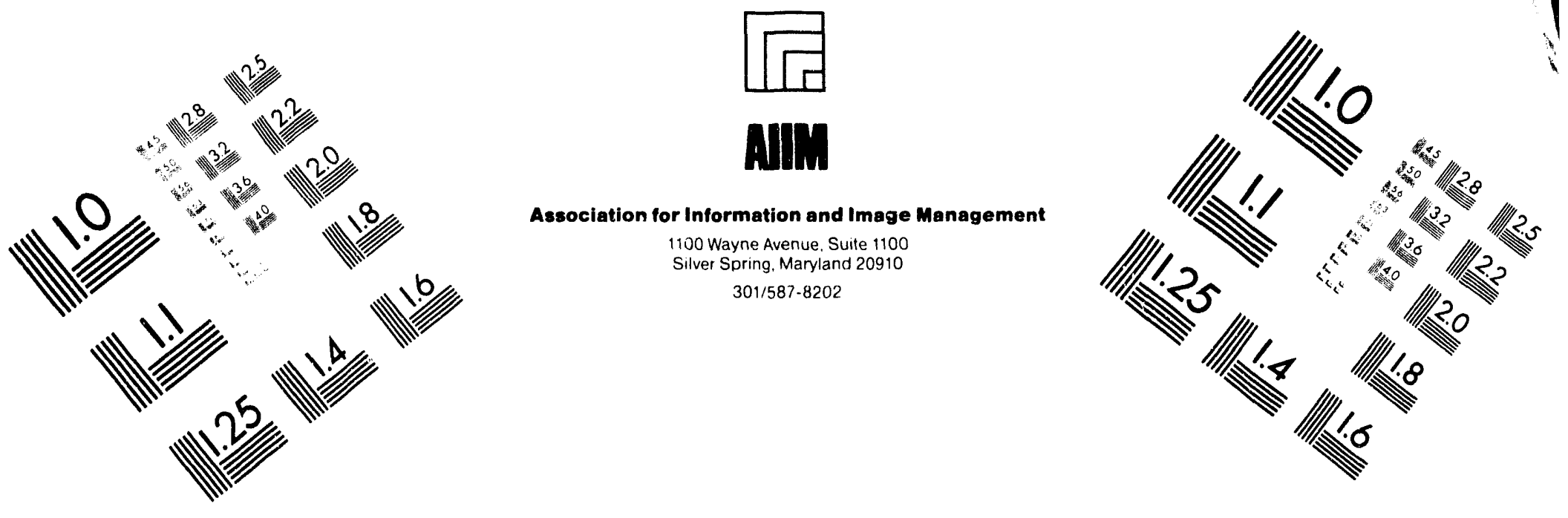

\title{
Centimeter
}

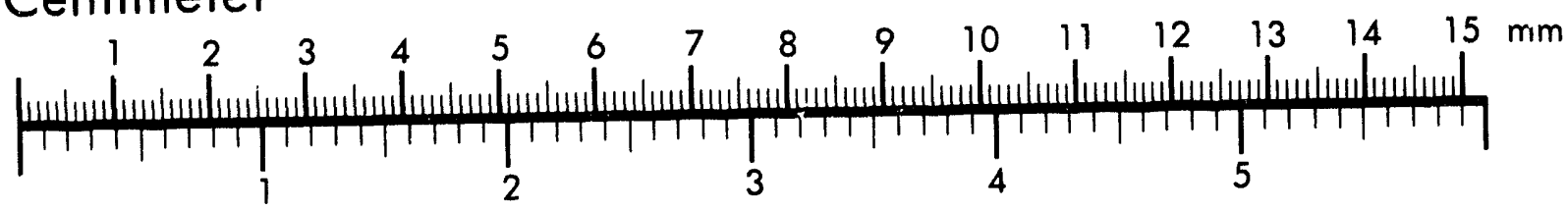
Inches
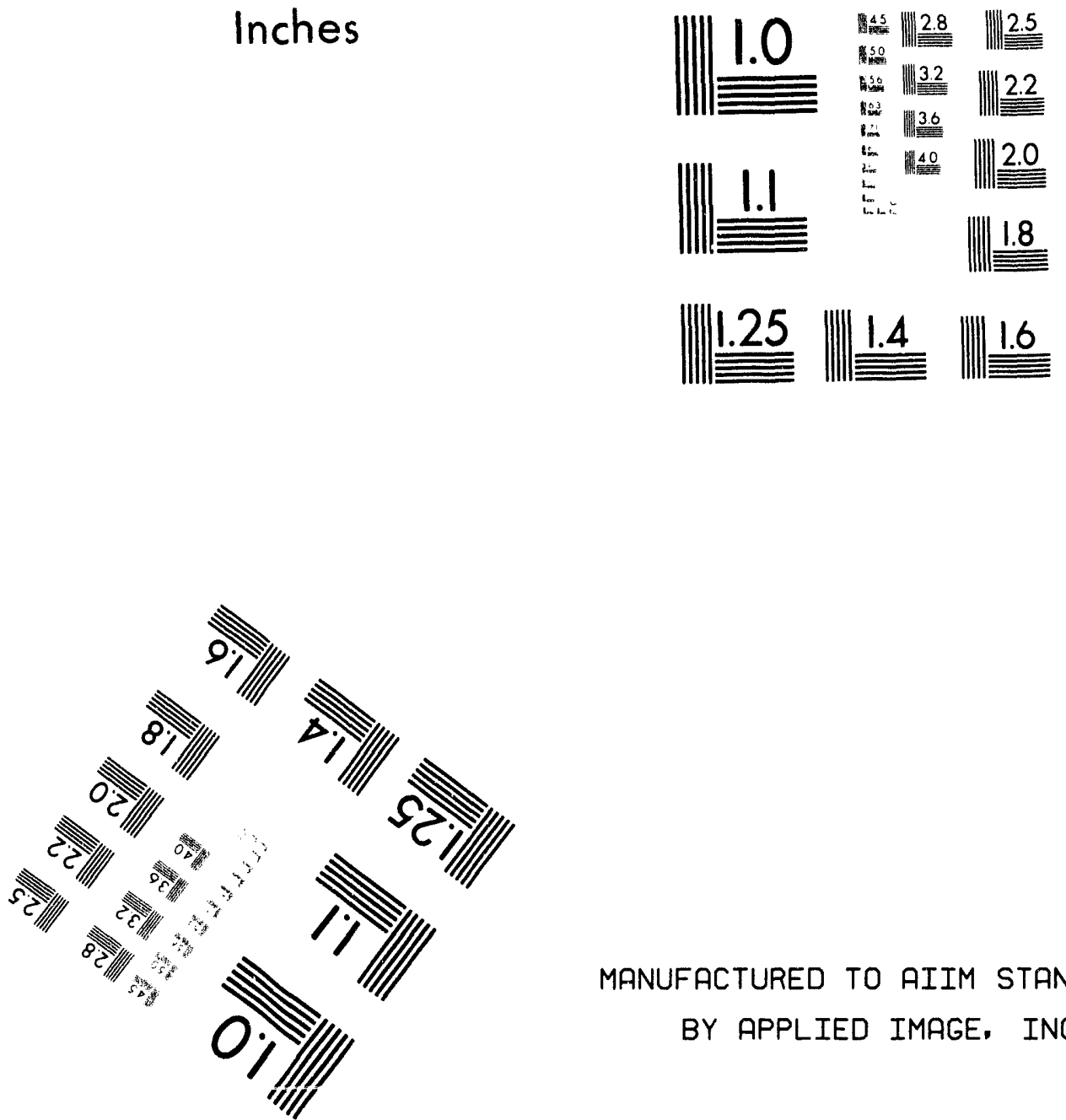

MANUFACTURED TO AIIM STANDARDS

BY APPLIED IMAGE, INC.

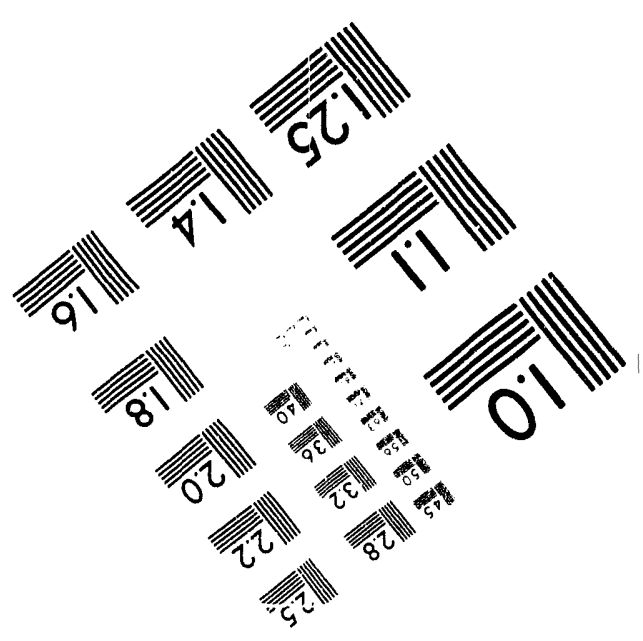



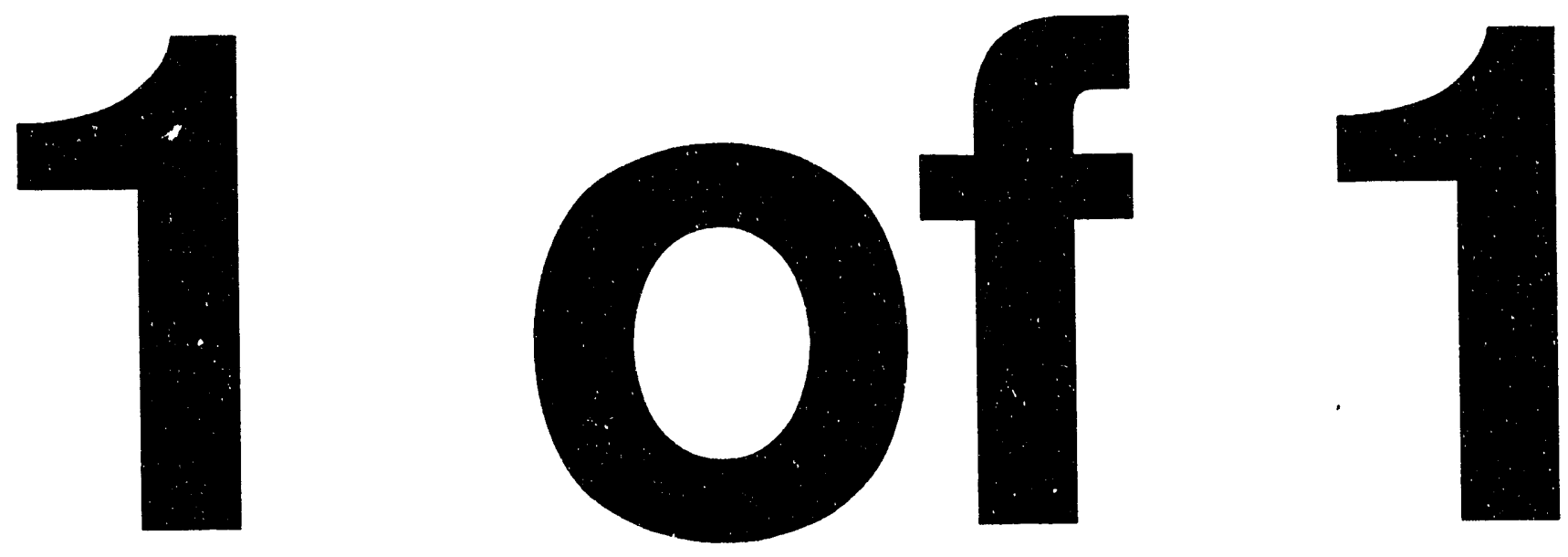


\section{LOT NO. 2 OF FRIT 202 FOR DWPF COLD RUNS (U)}

by

R. F. Schumacher

Westinghouse Savannah River Company

Savannah River Site

Aiken, South Carolina 29808

This paper was prepared in connection with work done under the above contract number with the U. S.

Department of Energy. By acceptance of this paper, the publisher and/or recipient acknowledges the U. S.

Government's right to retain a nonexclusive, royalty-free license in and to any copyright covering this paper, along with the right to reproduce and to authorize others to reproduce all or part of the copyrighted paper. 


\section{DISCLAIMER}

This report was prepared as an account of work sponsored by an agency of the United States Government. Neither the United States Government nor any agency thereof, nor any of their employees, makes any warranty, express or implied, or assumes any legal liability or responsibility for the accuracy, completeness, or usefulness of any information, apparatus, product, or process disclosed, or represents that its use would not infringe privately owned rights. Reference herein to any specific commercial product, process, or service by trade name, trademark, manufacturer, or otherwise does not necessarily constitute or imply its endorsement, recommendation, or favoring by the United States Government or any agency thereof. The views and opinions of authors expressed herein do not necessarily state or reflect those of the United States Government or any agency thereof.

This report has been reproduced directly from the best available copy.

Available to DOE and DOE contractors from the Office of Scientific and Technical Information, P. O. Box 62, Oak Ridge, TN 37831; prices available from (615) $576-8401$.

Available to the public from the National Technical Information Service, U. S. Department of Commerce, 5285 Port Royal Rd., Springfield, VA 22161. 
Keywords: DWPF, WAPS, glass frit, analyses

Retention Time: Permanent

CC. E.W. Holtzscheiter, 773-A

N.E. Bibler, 773-A

J.T. Carter, 704-T

L.F. Landon,

C.T. Randall,

N.D. Hutson,

K.G. Brown,

J.F. Sproull, 704-S

S.L. Marra, 704-S

H. Moore, 704-S

L.J. Jones, 704-27S

B. Latrace, BH-313

P.E. Lowe, 773-42A

Glass Tech, (10)

DC\&RM, 773-52A (4)

To: $\quad$ M.J. Plodinec, 773-A

From: R.F. Schumacher, 773-42A

April 5, 1993

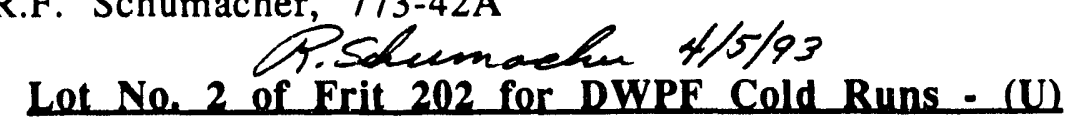

\section{SUMMARY}

The following report was prepared at the end of 1992 and summarizes the evaluation of the second lot sample of DWPF Frit 202 from Cataphote Inc.

Publication of this report was delayed until the results from the carbon analyses could be included. To avoid confusion the frit specifications presented in this report were those available at the end of 1992. The specifications were slightly modified early in 1993.

The frit was received and evaluated for moisture, particle size distribution, organic-inorganic carbon and chemical composition. Moisture content and particle size distribution were determined on a representative sample at SRTC. The moisture content was within specification. The particle size determination indicated that there was a fraction of a percent more coarse frit ( +80 mesh) than the specified amount. The fine end of the distribution was within specification. A representative sample was submitted to Corning Engineering Laboratory Services for chemical analyses. The sample was split and two dissolutions prepared. Each dissolution was analyzed on two separate days. The results indicate that there is a high probability $(>95 \%)$ that the silica content of this frit was below the specification limit of $77.0 \pm 1.0 \mathrm{wt} \%$. 
The average of the four analyzed values was $75.3 \mathrm{wt} \%$ with a standard deviation of $0.21 \mathrm{wt} \%$. All other oxides were within the elliptical limits established for this product. Two control standard frit samples were submitted and analyzed at the same time. The silica determination for the Frit 202 Reference Standard was $1.5 \mathrm{wt} \%$ below the expected value and the total of all the oxides anafyzed was approximately $98 \mathrm{wt} \%$. This silica analysis appeared to be incorrect. A sample of 165 standard was also included as a control and this analysis provided the expected values.

DWPF Lot 1 was very similar to the Lot 1 sample which was also low in silica. This material was outside the elliptical band of acceptability. The vendor was notified that the material was not acceptable for DWPF cold runs but would be usable at TNX.

\section{INTRODUCTION}

In the DWPF, glass forming chemicals will be added to the waste in the form of premelted glass frit ${ }^{1}$. On an oxide weight basis, DWPF glass will consist of approximately $64 \mathrm{wt} \%$ glass frit, $8 \mathrm{wt} \%$ precipitate hydrolysis aqueous product, and $28 \mathrm{wt} \%$ sludge. The glass frit and the precipitate hydrolysis aqueous product together make up what is called the glass-former composition. Glass Frit 202 was developed to provide a glass which is processable in the DWPF melter, compatible with a wide variety of projected waste types, and produces a waste form which has acceptable leach resistance.

The Waste Acceptance Preliminary Specifications, (WAPS) ${ }^{2}$ require that the DWPF control the consistenc'; of the waste glass product. As described in the Waste Form Compliance Plan (WCP) ${ }^{3}$, this will be achieved through control of the chemical composition of the glass product. Since the glass frit purchased by DWPF will constitute approximately two thirds of the glass product, control of the composition of the frit is an important part of meeting the WAPS. Current plans are to control the composition of the frit through the procurement specifications ${ }^{4}$ and chemical analyses of representative lot samples. A summary of the chemical and physical specifications for Frit 202 is presented in Table 1.

The total undesirable components is equal to 100 minus the actual analysis of the major oxide components as listed in Table 1 and includes but is not limited to $\mathrm{Al}, \mathrm{Fe}, \mathrm{Mn}, \mathrm{Ni}, \mathrm{Cr}, \mathrm{Pb}, \mathrm{Ti}, \mathrm{F}, \mathrm{Cl}$. Additional undesirable components $>0.05 \mathrm{wt} \%$ shall be reported along with their amount in the certificate of conformance. The moisture content of each lot of material shall be less than 0.1 wt\%. The equivalent carbon as measured by a Chemical Oxygen Demand (COD) shall be less than $0.1 \mathrm{wt} \%$ equivalent carbon. The particle size distribution of each lot of frit must be such that greater than or equal to $99.0 \mathrm{wt} \%$ passing through a Tyler 80 mesh screen, and less than $10 \mathrm{wt} \%$ passing through a Tyler 200 mesh screen. [Note: The Tyler and U.S. Standard are equivalent at 80 and 200 mesh openings.] The material must be free flowing. 
Table 1

Chemical and Physical Specification Frit 202 (Dec.1992)

$\begin{array}{lc}\text { Component } & \text { Concentration (wt } \%) \\ \mathrm{SiO}_{2} & 77.0 \pm 1.0 \\ \mathrm{Na}_{2} \mathrm{O} & 6.0 \pm 0.5 \\ \mathrm{~B}_{2} \mathrm{O}_{3} & 8.0 \pm 0.5 \\ \mathrm{Li} 2 \mathrm{O} & 7.0 \pm 0.5 \\ \mathrm{MgO} & 2.0 \pm 0.25 \\ \mathrm{Major} \text { Components } & \text { Sum of Above } \\ & \\ \mathrm{Chemical} & \text { Maximum (wt\%) } \\ \mathrm{Al} & 1.0 \\ \mathrm{Fe} & 0.2 \\ \mathrm{Mn} & 0.2 \\ \mathrm{Ni} & 0.2 \\ \mathrm{Cr} & 0.1 \\ \mathrm{~Pb} & 0.1 \\ \mathrm{Ti} & 0.15 \\ \mathrm{~F} & 0.05 \\ \mathrm{C} & 0.05 \\ \mathrm{Undesirable} \text { Component } & 2.25 \text { (As Oxides) }\end{array}$

A qualification sample of Cataphote Frit ${ }^{5}$ was evaluated at the end of 1989. The particle size distribution was within specification. The chemical analyses indicated that the silica level was at the lower end of the specification and may have been outside the limit by $0.1 \mathrm{wt} \%$. The boron level was at the upper limit of the specification. The initial qualifications of all of the presently qualified frit vendors 6 (Cataphote, Apec, and Ferro Corp.) was described. The first lot of Cataphote Frit 202 was unacceptable 7 due to the silica level being below the specification limit. All of the other properties were within the specification. The following report describes the evaluation of the second lot of DWPF Frit 202 for Cold Runs.

\section{EXPERIMENTAL}

A sample of Cataphote DWPF Lot No. 2 was received at the Savannah River Technical Center on October 26, 1992. The sample was contained in a steel quart container inside a sealed steel one gallon container. The material was . labeled as follows:

PROD. CODE SR FRIT 202

LOT 22010

DATE 10-22-92

OPER. J. PURVIS

QCTECH. R. TRIGG

TA $00717 \mathrm{H}$ 
The material was opened and split into eight identical samples by the Quantachrome $^{\mathrm{TM}}$ rotating riffler according to Glass Technology Procedure ${ }^{8}$ GTOP 3-024. All subsequent samples were obtained with the riffler. Two samples were immediately removed and the moisture for these samples was determined by the GTOP $3-013^{\prime}$ procedures. After the moisture was determined the dry material was placed in a nest of sieves and mechanically classified on a Ro-Tap ${ }^{\mathrm{TM}}$ shaker for 15 minutes using the Ro-Tap ${ }^{\mathrm{TM}}$ procedures and the procedures outlined in ASTM C-429 and C-92.

A random sample from the riffler was sent to Corning Engineering Laboratory Services (CELS) Corning, New York, for complete chemical analysis. Two "standard" frit samples were included for control. One control sample consisted of Frit 202 Reference Standard while a second sample was the Frit 165 Standard. Both of these materials have been thoroughly analyzed and the results described previously.9,10 An additional sample was sent to the Savannah River Technology Center-Analytical Development Section for total organic and inorganic carbon determination. This test has been found to be comparable to the Chemical Oxygen Demand test ${ }^{9}$.

\section{RESULTS AND DISCUSSION}

\section{Moisture and Particle Size Distribution}

The moisture and measured particle size distribution for the two samples is presented in Table 2. The results from the two samples were in close agreement. The material was dry with less than the $0.1 \mathrm{wt} \%$ moisture. The coarse frit (greater than 80 mesh) was slightly greater than the 1 wt\% specified. The fine end of the distribution was less than $10 \mathrm{wt} \%$, as specified. The material met the moisture specification, however, the particle size was a fraction of a percent high on the coarse end.

Table 2

\begin{tabular}{lccc} 
& $\begin{array}{c}\text { Moisture and Particle } \\
\text { Lot } 2\end{array}$ & $\begin{array}{c}\text { Size Distribution } \\
\text { Lot } 2\end{array}$ & DWPF Lot 2 \\
E-51768- & $139-2$ & $139-3$ & Average \\
\hline Moisture & $\frac{\mathrm{Wt}_{0}}{0.00}$ & $\frac{\mathrm{Wt} \%}{0.00}$ & $\frac{\mathrm{Wt} \%}{\mathbf{0 . 0 0}}$
\end{tabular}

\begin{tabular}{|c|c|c|c|c|c|}
\hline Particl & le Size & $\mathrm{Wt}_{\mathrm{t}}$ & $\mathrm{Wt}_{\mathrm{t}}$ & $\mathrm{Wt}_{\mathrm{t}} \%$ & $\begin{array}{c}\text { Cumulative } \\
\text { Wt} \%^{2}\end{array}$ \\
\hline+451 & Mesh & 0.00 & 0.00 & 0.00 & 0.00 \\
\hline & Mesh & 1.25 & 1.15 & 1.20 & 1.20 \\
\hline+100 & Mesh & 12.85 & 13.06 & 12.96 & 14.16 \\
\hline+200 & Mesh & 79.23 & 79.11 & 79.17 & 93.33 \\
\hline-200 & Mesh & 6.67 & 6.68 & 6.67 & 100.00 \\
\hline
\end{tabular}




\section{Organic and Inorganic Carbon}

The total organic and inorganic carbon was determined by ADS with the total carbon analyzer. Three samples were submitted with a sample of Reference Standard 202. The results are presented in Table 3. The Reference Standard was the same order of magnitude as an evaluation of this material in January of 1990 . The carbon content of Lot 2 was much less than 0.1 wt\%.

Table 3

Total Carbon Analyses of DWPF Lot 2 and Ref. Std 202 (ppm)

\begin{tabular}{|c|c|c|c|c|}
\hline Sample No. & & $\begin{array}{c}\text { Total } \\
\text { Organic }\end{array}$ & $\begin{array}{c}\text { Total } \\
\text { Inorganic }\end{array}$ & $\begin{array}{l}\text { Total } \\
\text { Carbon }\end{array}$ \\
\hline E-51768-139-5A & Lot 2 & 73 & 52 & 125 \\
\hline$-5 B$ & $"$ & 30 & 31 & 61 \\
\hline$-5 C$ & $"$ & 31 & 46 & 77 \\
\hline $\begin{array}{l}\text { E-51768-139-RS } \\
\text { Ref.Std } 202\end{array}$ & $\begin{array}{l}\text { Avg. } \\
\text { (Ref.Std.) } \\
(1 / 12 / 90)\end{array}$ & $\begin{array}{l}45 \\
332\end{array}$ & $\begin{array}{l}43 \\
49\end{array}$ & $\begin{array}{l}88=0.009 \text { wt } \% \\
381=0.038 \text { wt } \% \\
336\end{array}$ \\
\hline
\end{tabular}

\section{Chemical Analysis}

The preliminary qualitative analysis, which was conducted by CELS for the Lot 1 material was not conducted on the second lot. The CELS laboratory split each of the three frit samples and prepared two dissolutions. Each of the glass dissolutions were analyzed on two different days by Atomic Spectroscopy. The resulting four analyses for each sample were reported along with the averages and standard deviations. The complete chemical analyses as received from CELS are included as Appendix A. Table 4 presents a summary of the results obtained from the CELS analyses of DWPF Lot 2 and compares these values to the specification limits. Cataphote's analysis of this material is included and will be discussed in a future summary report.

Review of the analyses of the second lot of Frit 202, including Appendix A, indicated that the glass frit was very similar to Lot 1 . The major oxides were within the specifications except $\mathrm{SiO}_{2}$ which was 0.7 wt\% below the minimum and $\mathrm{B}_{2} \mathrm{O}_{3}$ which was just slightly higher then the specification maximum by 0.13 wt\%. The agreement between the four CELS measurements was again excellent. The undesirable oxides were also well within the $2.25 \mathrm{wt} \%$ limit at $1.04 \mathrm{wt} \%$. The oxide sum totaled to $99.3 \mathrm{wt} \%$. The residual material may include small amounts of $\mathrm{CaO}, \mathrm{BaO}, \mathrm{ZrO}_{2}, \mathrm{~K}_{2} \mathrm{O}, \mathrm{SO}_{4}$, and some $\mathrm{H}_{2} \mathrm{O}$. 
TABLE 4

Summary of CELS Chemical Analyses of DWPF Frit 202 Lot 2

\begin{tabular}{|c|c|c|c|c|c|c|c|}
\hline$E-51768-139-$ & DWPF-2 & & & CELS11/92 & & & Cataphote \\
\hline $\begin{array}{l}\text { Species } \\
\text { Majors }\end{array}$ & $\begin{array}{r}\text { Specification } \\
\text { Amount } \\
(\text { W } \% \text { ) }\end{array}$ & $\begin{array}{r}\text { Range } \\
\text { Minimum } \\
(W t \%)\end{array}$ & $\begin{array}{r}\text { Range } \\
\text { Maximum } \\
(W+\%)\end{array}$ & $\begin{array}{r}\text { Analysis } \\
\text { Average* } \\
(\text { W } \% \text { ) }\end{array}$ & $\begin{array}{l}\text { Std.Dev. } \\
(W t \%)\end{array}$ & $\begin{array}{r}\text { Rel. Std } \\
\text { Dev. }\end{array}$ & $\begin{array}{r}\text { Analysis } \\
11 / 23 / 92 \\
(W t \%)\end{array}$ \\
\hline SiO2 & $77.0 \pm 1.0$ & 76.0 & 78.0 & 75.3 & 0.206 & $0.27 \%$ & $(76.90)$ \\
\hline $\mathrm{Na} 2 \mathrm{O}$ & $6.0 \pm 0.5$ & 5.5 & 6.5 & 6.08 & 0.037 & $0.61 \%$ & 5.87 \\
\hline Li2O & $7.0 \pm 0.5$ & 6.5 & 7.5 & 6.93 & 0.044 & $0.63 \%$ & 6.88 \\
\hline MOO & $2.0 \pm 0.25$ & 1.75 & 2.25 & 2.02 & 0.006 & $0.30 \%$ & 1.98 \\
\hline $\mathrm{B} 2 \mathrm{O} 3$ & $8.0 \pm 0.5$ & 7.5 & 8.5 & 8.63 & 0.010 & $0.12 \%$ & 7.97 \\
\hline Total & & & & 98.96 & & & 99.60 \\
\hline Undesirable* & $\begin{array}{r}<2.25 \\
\operatorname{Max}(W+\%)\end{array}$ & & 2.3 & 1.04 & & & \\
\hline 7.rO2 & & & & 0.018 & 0.004 & & 0.0055 \\
\hline $\mathrm{Al} 2 \mathrm{O} 3$ & $A \mid=1.0$ & & 1.89 & 0.31 & 0.012 & $3.87 \%$ & 0.29 \\
\hline $\mathrm{Fe} 2 \mathrm{O} 3$ & $F_{\theta}=0.2$ & & 0.29 & 0.026 & 0.000 & & 0.023 \\
\hline Mno & $M n=0.2$ & & 0.32 & 0.0006 & 0.000 & & 0.001 \\
\hline $\mathrm{NiO}$ & $\mathrm{Ni}=0.2$ & & 0.25 & 0.0006 & 0.000 & & $\mathrm{Ni}=.0001$ \\
\hline Cr2O3 & $C r=0.1$ & & 0.15 & $<.001$ & 0.000 & & $C r=.0001$ \\
\hline $\mathrm{PbO}$ & $\mathrm{Pb}=0.1$ & & 0.11 & $<.001$ & 0.000 & & $\mathrm{~Pb}=.0001$ \\
\hline $\mathrm{TiO}_{2}$ & $\mathrm{Ti}=0.15$ & & 0.25 & 0.0082 & 0.000 & & 0.029 \\
\hline $\mathrm{F}$ & $F=0.05$ & & 0.05 & $(A D S=.003)$ & & & 0.05 \\
\hline $\mathrm{Cl}$ & $\mathrm{Cl}=0.05$ & & 0.05 & $(A D S=0.16)$ & & & 0.009 \\
\hline Others $>0.05$ & & & & & & & \\
\hline $\mathrm{K} 2 \mathrm{O}$ & & & & & & & 0.029 \\
\hline 10 & & & & & & & 0.043 \\
\hline $\mathrm{BaO}$ & & & & & & & 0.002 \\
\hline$S O B$ & & & & $(A D S=<0.1)$ & & & 0.05 \\
\hline Total Oxide Wt\% & & & & 99.32 & & & 100.10 \\
\hline & & & "Average & 2 dissolutions & ated & $s(n=c$ & \\
\hline Moisture & $<0.1$ & & & 0.0 & & & \\
\hline$\infty$ & $<0.1$ & & & $(A D S=0.009)$ & & & \\
\hline Particle Size & $W t \%$ & & & (SRTC) & & & (e日.) \\
\hline Through $80 \mathrm{M}$ & $\geq 99.0$ & & & 98.8 & & & \\
\hline Through $200 \mathrm{M}$ & $<10.0$ & & & 6.67 & & & \\
\hline
\end{tabular}

Table 5 presents a summary of the CELS analysis for the Reference Standard Frit 202 and compares the analyzed values to the "Best Estimate" composition 8 which was obtained after numerous analyses at various laboratories. Review of this analysis did not show good agreement between the four silica measurements from CELS and the "Best Estimate" of the silica content. All of the other oxides did agree quite well with the best estimate values. In addition, it should be noted that the total of the analyzed oxides summed to only $98 \mathrm{wt} \%$. It was felt after reviewing this analysis that the silica determination was in error for this particular analysis. This will be discussed in detail in the summary report. It should be noted that the ADS analysis of chlorine was quite high compared to the accepted value. 
Table 5

Summary of CELS Chemical Analysis of 202 Reference Standard

\begin{tabular}{|c|c|c|c|c|c|c|}
\hline $\begin{array}{l}\text { E-51768-135 } \\
\text { Spocies } \\
\text { Majors }\end{array}$ & $\begin{array}{r}\text { DWPF-2S } \\
\text { Specification } \\
\text { Amount } \\
(W+\%)\end{array}$ & $\begin{array}{r}\text { Best Est. } \\
\text { Oct-90 } \\
(W t \%)\end{array}$ & $\begin{array}{r}\text { CELS } 11 / 92 \\
\text { Analysis } \\
\text { Average } \\
(W t \%) \\
\end{array}$ & $\begin{array}{r}\text { Diff. } \\
(w+\%)\end{array}$ & $\begin{array}{r}\text { Std. } \\
\text { Dev. } \\
(W+\%)\end{array}$ & $\begin{array}{r}\text { Rel Std. } \\
\text { Dev. }\end{array}$ \\
\hline $\mathrm{SiO2}$ & $77.0 \pm 1.0$ & 76.6 & 75.1 & 1.5 & 0.236 & $0.31 \%$ \\
\hline $\mathrm{NaZO}$ & $6.0 \pm 0.5$ & 5.9 & 5.88 & 0.02 & 0.033 & $0.56 \%$ \\
\hline Li2O & $7.0 \pm 0.5$ & 6.7 & 6.65 & 0.05 & 0.000 & $0.00 \%$ \\
\hline MEO & $2.0 \pm 0.25$ & 2.0 & 2.03 & -0.03 & 0.015 & $0.74 \%$ \\
\hline B2O3 & $8.0 \pm 0.5$ & 7.7 & 7.72 & -0.02 & 0.026 & $0.34 \%$ \\
\hline Total & & 98.9 & 97.38 & 1.52 & & \\
\hline Undesirable* & $\begin{array}{r}<2.25 \\
\text { Maximum }\end{array}$ & 1.1 & 2.62 & -1.52 & & \\
\hline $\mathrm{ZrO2}$ & & 0.02 & 0.027 & & & \\
\hline Al2O3 & 1.89 & 0.40 & 0.43 & -0.03 & 0.013 & $3.02 \%$ \\
\hline $\mathrm{Fe} 2 \mathrm{O} 3$ & 0.29 & 0.03 & 0.031 & 0 & 0.000 & \\
\hline Mno & 0.26 & $<.01$ & 0.0014 & & 0.000 & \\
\hline NiO & 0.25 & $<.01$ & 0.0006 & & 0.000 & \\
\hline $\mathrm{Cr} 2 \mathrm{O} 3$ & 0.15 & $<.01$ & $<.001$ & & 0.000 & \\
\hline $\mathrm{PbO}$ & 0.11 & 0.01 & 0.013 & 0 & 0.000 & \\
\hline TiO2 & 0.25 & 0.11 & 0.11 & 0 & 0.000 & \\
\hline $\mathbf{F}$ & 0.05 & 0.03 & $A D S=0.03$ & 0 & 0.000 & \\
\hline $\mathrm{Cl}$ & 0.05 & 0.01 & $A D S=0.15$ & -0.14 & 0.000 & \\
\hline Others >0.05 & & & & & & \\
\hline $\mathrm{K} 2 \mathrm{O}$ & & 0.19 & & & & \\
\hline CaO & & 0.12 & & & & \\
\hline $\mathrm{B}=\mathrm{O}$ & & 0.04 & & & & \\
\hline Total Oxide & & 99.86 & 97.99 & 1.87 & & \\
\hline Mois & & & & & & \\
\hline$\infty$ & & $<.02$ & (ADS <.04) & & & \\
\hline
\end{tabular}

Table 6 presents a summary for the CELS chemical analysis of the Frit 165 control glass. The sample of Frit 165 was carefully analyzed in 1985 . The $\mathrm{SiO}_{2}$ was determined ten times while the remainder of the major oxides were determined sixteen times. An additional four analyses of this glass were carried out in 1989 and 19908. The recent CELS analysis is in excellent agreement with all of the previous analyses. The $\mathrm{SiO}_{2}$ value of this analysis is 0.2 wt\% below than the original 1985 analyses. The total for all the major oxides is identical. This analysis verifies the Lot 2 analysis. 
Table 6

Summary of CELS Chemical Analysis of Frit 165

\begin{tabular}{|c|c|c|c|c|c|c|}
\hline$E-51768-13$ & $.165 S 2$ & & CELS Analy. & & & \\
\hline $\begin{array}{l}\text { Species } \\
\text { Majors }\end{array}$ & $\begin{array}{r}\text { CELS Average } \\
3 / 15 / 85 \\
(W+\%)\end{array}$ & $\begin{array}{l}\text { Sigma } \\
(W+\%)\end{array}$ & $\begin{array}{l}\text { Average } \\
\text { Nov-92 } \\
(W t \%)\end{array}$ & $\begin{array}{l}\text { Diff. } \\
(W \%)\end{array}$ & $\begin{array}{l}\text { Sigma } \\
(W t \%)\end{array}$ & $\begin{array}{r}\text { Rel. Std. } \\
\text { Dev. }\end{array}$ \\
\hline$\overline{\mathrm{SiO} 2}$ & 68.89 & 0.075 & 68.7 & 0.2 & 0.299 & $0.44 \%$ \\
\hline $\mathrm{Na} 2 \mathrm{O}$ & 12.16 & 0.045 & 12.1 & 0.06 & 0.058 & $0.48 \%$ \\
\hline Li2O & 6.96 & 0.029 & 6.87 & 0.09 & 0.068 & $0.99 \%$ \\
\hline MgO & 0.99 & 0.010 & 1.02 & -0.03 & 0.010 & $0.98 \%$ \\
\hline $\mathrm{B} 2 \mathrm{O} 3$ & 9.32 & 0.064 & 9.35 & -0.03 & 0.035 & $0.37 \%$ \\
\hline Total & 99.31 & & 99.3 & 0.02 & & \\
\hline Undesirable* & & & & & & \\
\hline $\mathrm{ZrO2}$ & 0.99 & 0.017 & 1.25 & -0.26 & 0.015 & $1.20 \%$ \\
\hline Al2O3 & & & 0.037 & & 0.004 & $10.81 \%$ \\
\hline $\mathrm{Fe} 2 \mathrm{O} 3$ & & & 0.086 & & 0.000 & \\
\hline MNO & & & 0.0018 & & 0.000 & \\
\hline $\mathrm{NIO}$ & & & 0.0082 & & 0.000 & \\
\hline $\mathrm{Cr} 2 \mathrm{O} 3$ & & & 0.016 & & 0.000 & $0.00 \%$ \\
\hline $\mathrm{PBO}$ & & & 0.0046 & & 0.000 & \\
\hline $\mathrm{TIO} 2$ & & & 0.003 & & 0.000 & \\
\hline $\mathbf{F}$ & & & & & & \\
\hline & & & & & & \\
\hline Others $>0.05$ & & & & & & \\
\hline Total Oxides & & & 99.45 & & & \\
\hline
\end{tabular}

In general these chemical analyses appear to be accurate, however the silica analysis of the Reference Standard Frit 202 is suspect. The conclusion that the $\mathrm{SiO}_{2}$ level for DWPF-2 was outside the specification is maintained and points out the difficulty in meeting multiple interrelated specifications. This has been thoroughly discussed in previous reports 8,9 . In order to compensate for meeting the five interrelated specifications the rectangular specification limits were transformed to elliptical limits with an area increase of $25 \%$. This should compensate for the requirement of meeting five major specifications. In addition there is a band on either side of the ellipse which describes the $95 \%$ confidence limits due to measurement variability $( \pm 2$ sigma). These ellipses are shown in Figure 1 along with the locations of DWPF-2, the 202 Reference Standard, and the "Best Estimate" value. Unfortunately, the Reference Standard silica analysis makes the analysis appear worse than it is. 

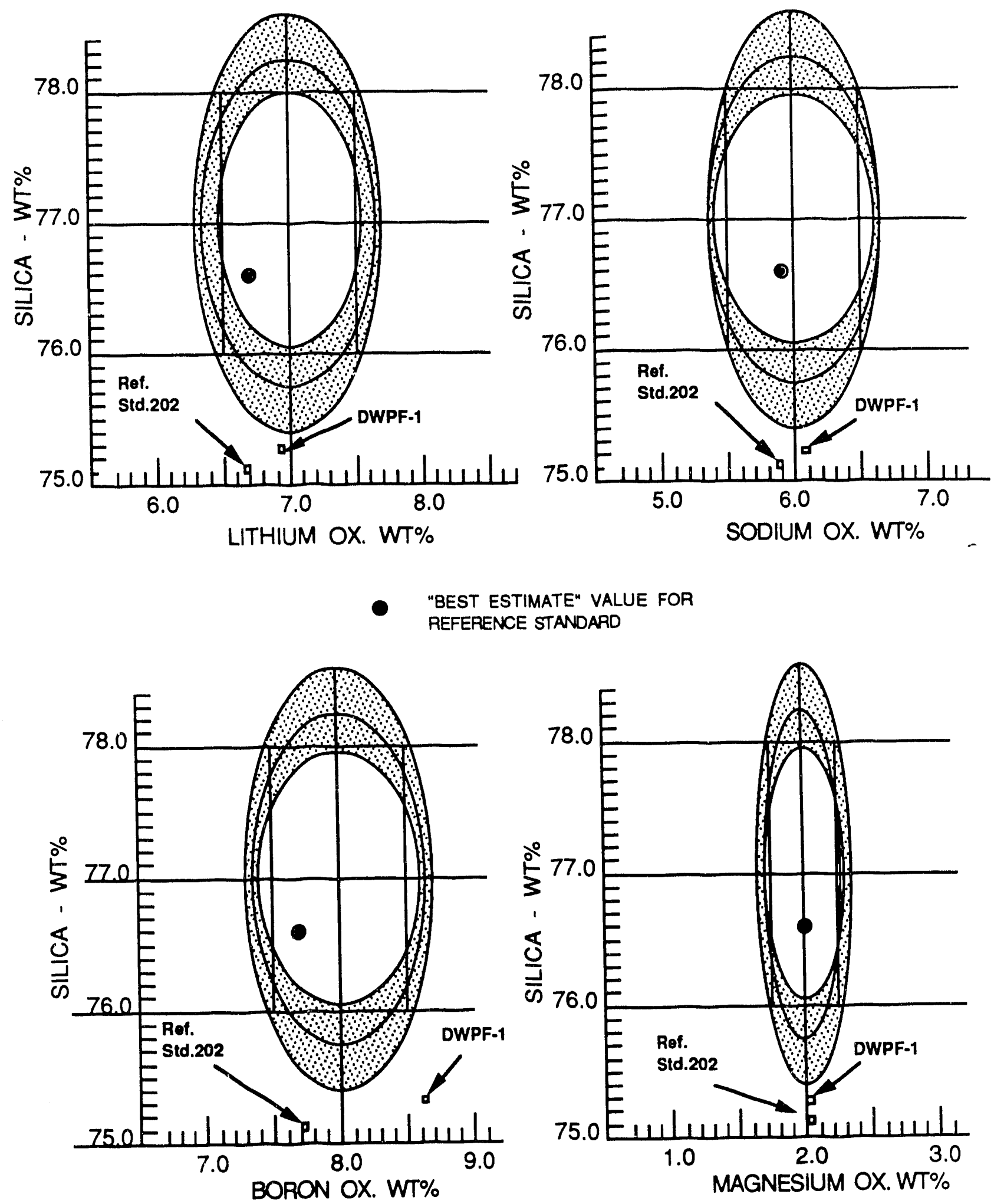

Figure 1. Graphical Representation of Lot 2 and Ref. Std. 202 Plotted on Elliptical Limit Plots. 


\section{CONCLUSIONS}

1. The particle size distribution of DWPF Frit 202 Lot 1 had a fraction of a percent more of the +80 mesh material than specified. The moisture content was well within the specification.

2. The total carbon content as measured by total carbon was much less than the specified 0.1 wt $\%$.

3. The chemical analysis of DWPF Frit 202 Lot 1 shows that the chemical composition of the frit was low in $\mathrm{SiO}_{2}$. All other oxides, including $\mathrm{B}_{2} \mathrm{O}_{3}$ were within the specification or within the elliptical limits. Lot 2 was very similar to Lot 1 .

4. The DWPF Frit 202 Lot 2 was not acceptable for DWPF Cold Runs but it was acceptable for use at TNX. The vendor was notified that the material was not acceptable.

\section{QUALITY ASSURANCE}

This work was a continuation of efforts under the Frit Qualification 11 and Errors of Frit 12 tasks. The procedures employed in this study were ASTM approved or as presented in the Glass Technology Procedures Manual 7 . Well documented controls were used for the chemical analyses and all data was documented 14 .

\section{ACKNOWLEDGMENTS}

The author wishes to acknowledge the efforts of Roberta Hooks for performing the physical evaluations of the frit and Carol Jantzen, who established the chemical analysis contract with CELS and was the Technical Representative. 


\section{REFERENCES}

1. DWPF Waste Form Compliance Plan, Part 3, Item 500, WSRC-IM-91-116-5

2. U.S. Department of Energy, Office of Civilian Radioactive Waste Management, "Waste-Form Acceptance Preliminary Specifications for Vitrified High Level Waste Forms", June 1991.

3. WSRC-SW4-6 DWPF Waste Form Compliance Plan, Rev. 0, March 1990. (WSRC-RP-90-367. March 28, 1990).

4. "Specification for Procurement of Cold Run Frit 202, Specification No. OPSDTE-910003", Rev.0, February 20, 1991.

5. Schumacher, R.F., "DWPF Frit Qualification-Cataphote Inc.(U)", WSRC-RP89-1360, December 22, 1989.

6. Schumacher, R.F., "DWPF Frit Qualification-Summary", WSRC-TR-90-160, April 6, 1990.

7. Schumacher, R.F., "Lot No.1 of Frit 202 for DWPF Cold Runs", WSRC-TR-92-569, April 1, 1992.

8. "Glass Technology Procedures Manual (U)," Procedure Manual L 13-1, WSRC, Aiken SC.

9. Schumacher, R.F., "Errors of DWPF Frit Analyses-Reference Standard-II (U)", WSRC-RP-90-1219. October 22, 1990.

10. Schumacher, R.F., "Errors of DWPF Frit Analysis - Final Report-(U)" WSRC-RP-92-37, January 24, 1992.

11. Schumacher, R.F., "Acceptance of Purchased Frit by DWPF-(U)", WSRC-MS91-507, 94th Annual Meeting Amer. Ceram. Soc. Minn., MN, April 1992.

12. Schumacher, R.F., "Research and Development Plan DWPF Frit Qualification-(U)", WSRC-RP-89-362, June 1, 1989.

13. Schumacher, R.F., "Quality Assurance/Assessment Plan Errors of DWPF Frit Analyses (U)", WSRC-RP-89-50, May 1, 1989.

14. Notebook No. E-51768, DPSTN-4648, R.F. Schumacher. 
Carming Incorporaned CIS-Laboramy Services

Technolowy Sales \& Licensing

HP.ME 03078 G6

Corting, New York 14831

$800-2352357$

607-974-6601

f2x 607-974-6522

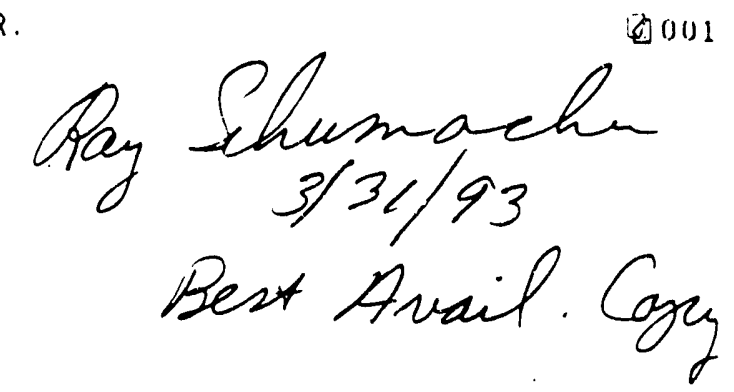

FAX TRANSWITTAL SHERT

GORNINr:

DATE: $\quad$ November 20, 1992

TIME: $2: 30$ p.m.

TO:

Ms. Carol Jantzea

WSRC

FAX No.: 803-725-4704

FROE: Linda P. Adams

Corning Incorporated

SUBJECT: Report: 3 DWPF Frit samples 2

TOTAT, Number of Pages to follow: 4

COMMTN'L'S : 
Corning incorposared

CEIS-Laboratory Services

Technology Sales \&c Licensing

HP MEE 03078 G6

Coraiog, New York 14831

800-235-2357

$007-974-6601$

iax 607-974-6522

Dr. Carol M. Jantzen

October 26, 1992

WSRC

P.O. BOX 616

Aiken, South Carolina 29808

CELS Client No.: 11988-040

Date Received : 06-NOV-92

Date Reported : 20-NOV-92

subcontract No. AA07192N

Reviowed \& Approved by:

corning

Copy to: cers File

Page 1 of 4

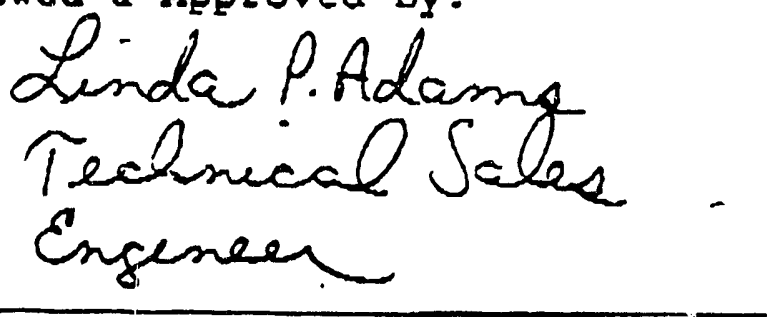

\section{SAMPLE IDENTIFICATION:}

\section{DWPF Frit samples: DWPE 2 \\ DWPE 25 \\ DWPF $165 \mathrm{~S}$}

\section{ANALYSIS REPORTED:}

\section{Exhibit}

A

Quantitative Chemical Analysis by

Atomic spectroscopy

\section{COMMENTS:}

Client Purchase Order No. AA07192N

Direct guestions regarding this report to Linda P. Adams, CELs office. NoTE: This report shall not be reproduced except in full, without the expressad parmission of cés - Laboratorý servicé. 
LABORATORY ANALYSIS REPORT

C.FIS :i iant No.: 11988-040
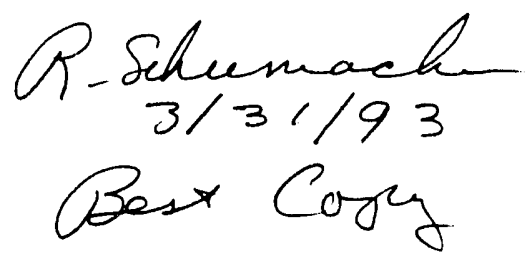

Page 2 of 4

Exhibit B: Quantitative Chemical Analysis by Atomic spectroscopy

Sample Description: DWPF-2

Lab I.D. NO.: 25675-92

$\begin{array}{llllll} & & & \text { Dis } 2 & \text { Mean } & \text { Std. Dev. }\end{array}$

\begin{tabular}{|c|c|c|c|c|c|c|}
\hline $\begin{array}{l}\text { Al } 203 \\
\text { Al }\end{array}$ & $\begin{array}{l}0.30 \\
0.16\end{array}$ & $\begin{array}{l}0.32 \\
0.17\end{array}$ & $\begin{array}{l}0.30 \\
0.16\end{array}$ & $\begin{array}{l}0.32 \\
0.17\end{array}$ & $\begin{array}{l}0.31 \\
0.17\end{array}$ & $\begin{array}{l}0.012 \\
0.006\end{array}$ \\
\hline $\begin{array}{l}\text { B203 } \\
B\end{array}$ & $\begin{array}{l}8.62 \\
2.68\end{array}$ & $\begin{array}{l}8.64 \\
2.68\end{array}$ & $\begin{array}{l}8.63 \\
2.68\end{array}$ & $\begin{array}{l}8.62 \\
2.68\end{array}$ & $\begin{array}{l}8.63 \\
2.68\end{array}$ & $\begin{array}{l}0.010 \\
0.000\end{array}$ \\
\hline $\begin{array}{l}\mathrm{Cr} 203 \\
\mathrm{Cr}\end{array}$ & $\begin{array}{r}<0.001 \\
<0.0007\end{array}$ & $\begin{array}{r}<0.001 \\
<0.0007\end{array}$ & $\begin{array}{r}<0.001 \\
<0.0007\end{array}$ & $\begin{array}{r}<0.001 \\
<0.0007\end{array}$ & $\begin{array}{l}<0.001 \\
<0.0007\end{array}$ & $\begin{array}{l}0.000 \\
0.000\end{array}$ \\
\hline $\begin{array}{l}\text { Ee203 } \\
\text { Fe }\end{array}$ & $\begin{array}{l}0.026 \\
0.018\end{array}$ & $\begin{array}{l}0.026 \\
0.018\end{array}$ & $\begin{array}{l}0.026 \\
0.018\end{array}$ & $\begin{array}{l}0.026 \\
0.018\end{array}$ & $\begin{array}{l}0.026 \\
0.018\end{array}$ & $\begin{array}{l}0.000 \\
0.000\end{array}$ \\
\hline $\begin{array}{l}\operatorname{Li} 20 \\
\text { Li }\end{array}$ & $\begin{array}{l}6.91 \\
3.21\end{array}$ & $\begin{array}{l}6.98 \\
3.24\end{array}$ & $\begin{array}{l}6.88 \\
3.20\end{array}$ & $\begin{array}{l}6.95 \\
3.23\end{array}$ & $\begin{array}{l}6.93 \\
3.22\end{array}$ & $\begin{array}{l}0.044 \\
0.018\end{array}$ \\
\hline $\begin{array}{l}\text { Mgo } \\
\text { Mg }\end{array}$ & $\begin{array}{l}2.01 \\
1.21\end{array}$ & $\begin{array}{l}2.02 \\
1.22\end{array}$ & $\begin{array}{l}2.01 \\
1.21\end{array}$ & $\begin{array}{l}2.02 \\
1.22\end{array}$ & $\begin{array}{l}2.02 \\
1.22\end{array}$ & $\begin{array}{l}0.006 \\
0.006\end{array}$ \\
\hline $\begin{array}{l}\mathrm{MnO} \\
\mathrm{mn}\end{array}$ & $\begin{array}{l}0.0006 \\
0.0005\end{array}$ & $\begin{array}{l}0.0005 \\
0.0004\end{array}$ & $\begin{array}{l}0.0006 \\
0.0005\end{array}$ & $\begin{array}{l}0.0006 \\
0.0005\end{array}$ & $\begin{array}{l}0.0006 \\
0.0005\end{array}$ & $\begin{array}{l}0.000 \\
0.000\end{array}$ \\
\hline $\begin{array}{l}\mathrm{Na20} \\
\mathrm{Na}\end{array}$ & $\begin{array}{l}6.05 \\
4.49\end{array}$ & $\begin{array}{l}6.12 \\
4.54\end{array}$ & $\begin{array}{l}6.04 \\
4.48\end{array}$ & $\begin{array}{l}6.09 \\
4.51\end{array}$ & $\begin{array}{l}6.08 \\
4.51\end{array}$ & $\begin{array}{l}0.037 \\
0.026\end{array}$ \\
\hline $\begin{array}{l}\text { NiO } \\
\text { Ni }\end{array}$ & $\begin{array}{l}0.0005 \\
0.0005\end{array}$ & $\begin{array}{l}0.0005 \\
0.0004\end{array}$ & $\begin{array}{l}0.0006 \\
0.0005\end{array}$ & $\begin{array}{l}0.0006 \\
0.0005\end{array}$ & $\begin{array}{l}0.0005 \\
0.0005\end{array}$ & $\begin{array}{l}0.000 \\
0.000\end{array}$ \\
\hline $\begin{array}{l}\text { Pbo } \\
\text { Pb }\end{array}$ & $\begin{array}{l}<0.001 \\
<0.0009\end{array}$ & $\begin{array}{l}<0.001 \\
<0.0009\end{array}$ & $\begin{array}{l}<0.001 \\
<0.0009\end{array}$ & $\begin{array}{r}<0.001 \\
<0.0009\end{array}$ & $\begin{array}{l}<0.001 \\
<0.0009\end{array}$ & $\begin{array}{l}0.000 \\
0.000\end{array}$ \\
\hline $\begin{array}{l}\mathrm{SiO} 2 \\
\mathrm{si}\end{array}$ & $\begin{array}{l}75.1 \\
35.1\end{array}$ & $\begin{array}{l}75.5 \\
35.3\end{array}$ & $\begin{array}{l}75.4 \\
35.2\end{array}$ & $\begin{array}{l}75.1 \\
35.1\end{array}$ & $\begin{array}{l}75.3 \\
35.2\end{array}$ & $\begin{array}{l}0.200 \\
0.096\end{array}$ \\
\hline $\begin{array}{l}\mathrm{TiO2} \\
\mathrm{Ti}\end{array}$ & $\begin{array}{l}0.0083 \\
0.0050\end{array}$ & $\begin{array}{l}0.0083 \\
0.0050\end{array}$ & $\begin{array}{l}0.0077 \\
0.0046\end{array}$ & $\begin{array}{l}0.0086 \\
0.0052\end{array}$ & $\begin{array}{l}0.0082 \\
0.0050\end{array}$ & $\begin{array}{l}0.000 \\
0.000\end{array}$ \\
\hline $\begin{array}{l}\mathrm{ZrO2} \\
\mathrm{Zr}\end{array}$ & $\begin{array}{l}0.014 \\
0.010\end{array}$ & $\begin{array}{l}0.016 \\
0.012\end{array}$ & $\begin{array}{l}0.023 \\
0.017\end{array}$ & $\begin{array}{l}0.018 \\
0.013\end{array}$ & $\begin{array}{l}0.018 \\
0.013\end{array}$ & $\begin{array}{l}0.004 \\
0.003\end{array}$ \\
\hline
\end{tabular}

Oxide Total 99.29

Dis 1 and Dis 2 - Dissolution 1 and 2

Day $I$ and Day 2 - 1 st and $2 n$ anelysis , ...d? 
LABORATORY ANALYSIS REPORT

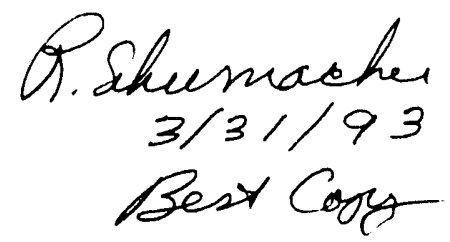

CELS Client No.: 11988-040

Page 3 of 4

Exhibit 3: Quantitative Chemical Aralysis by Atomic spectroscopy

Sample Description: DWEE-2S

Lab I.D. No.: 25675-92

oxides

Dis 1 Dis 2

Dis 1 Dis 2 Mean std. Dev. Day 1 Day 1

Day 2

Day 2

\begin{tabular}{|c|c|c|c|c|c|c|}
\hline $\begin{array}{l}\text { Al203 } \\
\text { Al }\end{array}$ & $\begin{array}{l}0.43 \\
0.23\end{array}$ & $\begin{array}{l}0.42 \\
0.22\end{array}$ & $\begin{array}{l}0.45 \\
0.24\end{array}$ & $\begin{array}{l}0.43 \\
0.23\end{array}$ & $\begin{array}{l}0.43 \\
0.23\end{array}$ & $\begin{array}{l}0.013 \\
0.008\end{array}$ \\
\hline $\begin{array}{l}\mathrm{B203} \\
\mathrm{B}\end{array}$ & $\begin{array}{l}7.75 \\
2.41\end{array}$ & $\begin{array}{l}7.70 \\
2.39\end{array}$ & $\begin{array}{l}7.74 \\
2.40\end{array}$ & $\begin{array}{l}7.7^{n} \\
2.39\end{array}$ & $\begin{array}{l}7.72 \\
2.40\end{array}$ & $\begin{array}{l}0.026 \\
0.010\end{array}$ \\
\hline $\begin{array}{l}\text { Cr2O3 } \\
\text { Cr }\end{array}$ & $\begin{array}{r}<0.001 \\
<0.0007\end{array}$ & $\begin{array}{r}<0.001 \\
<0.0007\end{array}$ & $\begin{array}{r}<0.001 \\
<0.0007\end{array}$ & $\begin{array}{r}<0.001 \\
<0.0007\end{array}$ & $\begin{array}{l}<0.001 \\
<0.0007\end{array}$ & $\begin{array}{l}0.000 \\
0.000\end{array}$ \\
\hline $\begin{array}{l}\mathrm{Fe} 203 \\
\mathrm{Fe}\end{array}$ & $\begin{array}{l}0.331 \\
0.822\end{array}$ & $\begin{array}{l}0.031 \\
0.022\end{array}$ & $\begin{array}{l}0.031 \\
0.022\end{array}$ & $\begin{array}{l}0.031 \\
0.022\end{array}$ & $\begin{array}{l}0.031 \\
0.0 .22\end{array}$ & $\begin{array}{l}0.000 \\
0.000\end{array}$ \\
\hline $\begin{array}{l}\operatorname{Li20} \\
\operatorname{Li}\end{array}$ & $\begin{array}{l}6.67 \\
3.10\end{array}$ & $\begin{array}{l}6.59 \\
3.06\end{array}$ & $\begin{array}{l}6.70 \\
3.11\end{array}$ & $\begin{array}{l}6.65 \\
3.09\end{array}$ & $\begin{array}{l}6.65 \\
3.09\end{array}$ & $\begin{array}{l}0.000 \\
0.000\end{array}$ \\
\hline $\begin{array}{l}\mathrm{MgO} \\
\mathrm{Mg}\end{array}$ & $\begin{array}{l}2.04 \\
1.23\end{array}$ & $\begin{array}{l}2.01 \\
1.21\end{array}$ & $\begin{array}{l}2.04 \\
1.23\end{array}$ & $\begin{array}{l}2.02 \\
1.22\end{array}$ & $\begin{array}{l}2.03 \\
1.22\end{array}$ & $\begin{array}{l}0.015 \\
1) .010\end{array}$ \\
\hline $\begin{array}{l}\text { Mno } \\
M n\end{array}$ & $\begin{array}{l}0.0014 \\
0.0011\end{array}$ & $\begin{array}{l}0.0013 \\
0.0010\end{array}$ & $\begin{array}{l}0.0014 \\
0.0011\end{array}$ & $\begin{array}{l}0.1913 \\
0.4010\end{array}$ & $\begin{array}{l}0.0014 \\
0.0011\end{array}$ & $\begin{array}{l}0.000 \\
0.000\end{array}$ \\
\hline $\begin{array}{l}\mathrm{Na20} \\
\mathrm{Na}\end{array}$ & $\begin{array}{l}5.85 \\
4.34\end{array}$ & $\begin{array}{l}5.90 \\
4.38\end{array}$ & $\begin{array}{l}5.92 \\
4.39\end{array}$ & $\begin{array}{l}5.86 \\
4.35\end{array}$ & $\begin{array}{l}5.88 \\
4.37\end{array}$ & $\begin{array}{l}0.033 \\
0.024\end{array}$ \\
\hline $\begin{array}{l}\mathrm{NiO} \\
\mathrm{Ni}\end{array}$ & $\begin{array}{l}0.0006 \\
0.0005\end{array}$ & $\begin{array}{l}0.0005 \\
0.0004\end{array}$ & $\begin{array}{l}0.0006 \\
0.0005\end{array}$ & $\begin{array}{l}0.0005 \\
0.0005\end{array}$ & $\begin{array}{l}0.0006 \\
0.0005\end{array}$ & $\begin{array}{l}0.000 \\
0.000\end{array}$ \\
\hline $\begin{array}{l}\text { Pbo } \\
\text { Pb }\end{array}$ & $\begin{array}{l}0.013 \\
0.012\end{array}$ & $\begin{array}{l}0.013 \\
0.012\end{array}$ & $\begin{array}{l}0.012 \\
0.011\end{array}$ & $\begin{array}{l}0.012 \\
0.011\end{array}$ & $\begin{array}{l}0.013 \\
0.012\end{array}$ & $\begin{array}{l}0.001 \\
0.001\end{array}$ \\
\hline $\begin{array}{l}\mathrm{siO2} \\
\mathrm{si}\end{array}$ & $\begin{array}{l}75.1 \\
35.1\end{array}$ & $\begin{array}{l}74.9 \\
35.0\end{array}$ & $\begin{array}{l}75.4 \\
35.2\end{array}$ & $\begin{array}{l}74.9 \\
35.7\end{array}$ & $\begin{array}{l}75.1 \\
35.1\end{array}$ & $\begin{array}{l}0.236 \\
0.096\end{array}$ \\
\hline $\begin{array}{l}\mathrm{TiO} 2 \\
\mathrm{Ti}\end{array}$ & $\begin{array}{l}0.11 \\
0.056\end{array}$ & 0.066 & $\begin{array}{r}0.11 \\
0.066\end{array}$ & $0.0 \frac{11}{06}$ & $\begin{array}{c}0.11 \\
0.066\end{array}$ & $\begin{array}{l}0.000 \\
0.000\end{array}$ \\
\hline \multirow[t]{2}{*}{$\begin{array}{l}\mathrm{ZrO} 2 \\
\mathrm{Zr}\end{array}$} & $\begin{array}{l}0.027 \\
0.020\end{array}$ & $\begin{array}{l}0.026 \\
0.019\end{array}$ & $\begin{array}{l}0.027 \\
0.020\end{array}$ & $\begin{array}{l}0.027 \\
0.020\end{array}$ & $\begin{array}{l}0.027 \\
0.020\end{array}$ & $\begin{array}{l}0.000 \\
0.000\end{array}$ \\
\hline & & & & & 97.97 & \\
\hline
\end{tabular}

Dis 1 and Dis 2 - Dissolution 1 and 2

Day 1 and Day 2 - 1 st and 2 nd Analysis (read) 


\section{IABORATORY ANALISIS REPORT}

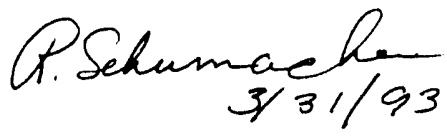

Best Coryz

page $\triangle$ OE 4

CELS Client No.: $11988-040$

Exhibit B: Quantitative Chemical Analysis by Atomic spectroscopy Sample Description: DWPF-1655

Lab I.D. NO.: 25675-92

Oxides

Dis 1 Day 1

$\begin{array}{ll}\text { Dis } 2 & \text { Dis } 1 \\ \text { Day } 1 & \text { Day } 2\end{array}$

Dis 2 Mean sta. Dev.

Day 2

\begin{tabular}{|c|c|c|c|c|c|c|}
\hline $\begin{array}{l}\text { Al203 } \\
\text { Al }\end{array}$ & $\begin{array}{l}0.036 \\
0.019\end{array}$ & $\begin{array}{l}0.034 \\
0.018\end{array}$ & $\begin{array}{l}0.035 \\
0.019\end{array}$ & $\begin{array}{l}0.043 \\
0.023\end{array}$ & $\begin{array}{l}0.037 \\
0.020\end{array}$ & $\begin{array}{l}0.004 \\
0.002\end{array}$ \\
\hline $\begin{array}{l}\mathrm{B203} \\
\mathrm{B}\end{array}$ & $\begin{array}{l}9.34 \\
2.90\end{array}$ & $\begin{array}{l}9.40 \\
2.92\end{array}$ & $\begin{array}{l}9.34 \\
2.90\end{array}$ & $\begin{array}{l}9.32 \\
2.89\end{array}$ & $\begin{array}{l}9.35 \\
2.30\end{array}$ & $\begin{array}{l}0.035 \\
0.013\end{array}$ \\
\hline $\begin{array}{l}\text { Cr203 } \\
\text { CE }\end{array}$ & $\begin{array}{l}0.016 \\
0.011\end{array}$ & $\begin{array}{l}0.016 \\
0.011\end{array}$ & $\begin{array}{l}0.016 \\
0.011\end{array}$ & $\begin{array}{l}0.016 \\
0.011\end{array}$ & $\begin{array}{l}0.016 \\
0.011\end{array}$ & $\begin{array}{l}0.000 \\
0.000\end{array}$ \\
\hline $\begin{array}{l}\mathrm{Fe} 203 \\
\mathrm{Ee}\end{array}$ & $\begin{array}{l}0.084 \\
0.059\end{array}$ & $\begin{array}{l}0.092 \\
0.064\end{array}$ & $\begin{array}{l}0.083 \\
0.058\end{array}$ & $\begin{array}{l}0.083 \\
0.058\end{array}$ & $\begin{array}{l}0.086 \\
0.060\end{array}$ & $\begin{array}{l}0.000 \\
0.000\end{array}$ \\
\hline $\begin{array}{l}\operatorname{Li20} \\
\mathrm{Li}\end{array}$ & $\begin{array}{l}6.85 \\
3.18\end{array}$ & $\begin{array}{l}6.78 \\
3.15\end{array}$ & $\begin{array}{l}6.91 \\
3.21\end{array}$ & $\begin{array}{l}6.93 \\
3.22\end{array}$ & $\begin{array}{l}6.87 \\
3.19\end{array}$ & $\begin{array}{l}0.068 \\
0.032\end{array}$ \\
\hline $\begin{array}{l}\text { MgO } \\
M g\end{array}$ & $\begin{array}{l}1.01 \\
0.61\end{array}$ & $\begin{array}{l}1.01 \\
0.61\end{array}$ & $\begin{array}{l}1.01 \\
0.61\end{array}$ & $\begin{array}{l}1.03 \\
0.62\end{array}$ & $\begin{array}{l}1.02 \\
0.61\end{array}$ & $\begin{array}{l}0.010 \\
0.005\end{array}$ \\
\hline $\begin{array}{l}\mathrm{MnO} \\
\mathrm{Mn}\end{array}$ & $\begin{array}{l}0.0017 \\
0.0013\end{array}$ & $\begin{array}{l}0.0018 \\
0.0014\end{array}$ & $\begin{array}{l}0.0018 \\
0.0014\end{array}$ & $\begin{array}{l}0.0017 \\
0.0014\end{array}$ & $\begin{array}{l}0.0018 \\
0.0014\end{array}$ & $\begin{array}{l}0.000 \\
0.000\end{array}$ \\
\hline $\begin{array}{l}\mathrm{Na2O} \\
\mathrm{Na}\end{array}$ & $\begin{array}{l}12.0 \\
8.90\end{array}$ & $\begin{array}{l}12.0 \\
8.90\end{array}$ & $\begin{array}{l}12.1 \\
8.98\end{array}$ & $\begin{array}{l}12.1 \\
8.98\end{array}$ & $\begin{array}{l}12.1 \\
8.94\end{array}$ & $\begin{array}{l}0.058 \\
0.040\end{array}$ \\
\hline $\begin{array}{l}\mathrm{NiO} \\
\mathrm{Ni}\end{array}$ & $\begin{array}{l}0.0083 \\
0.0065\end{array}$ & $\begin{array}{l}0.0084 \\
0.0066\end{array}$ & $\begin{array}{l}0.0081 \\
0.0064\end{array}$ & $\begin{array}{l}0.0081 \\
0.0064\end{array}$ & $\begin{array}{l}0.0082 \\
0.0065\end{array}$ & $\begin{array}{l}0.000 \\
0.000\end{array}$ \\
\hline $\begin{array}{l}\mathrm{PbO} \\
\mathrm{Pb}\end{array}$ & $\begin{array}{l}0.0046 \\
0.0043\end{array}$ & $\begin{array}{l}0.0047 \\
0.0044\end{array}$ & $\begin{array}{l}0.0043 \\
0.0040\end{array}$ & $\begin{array}{l}0.0046 \\
0.0043\end{array}$ & $\begin{array}{l}0.0046 \\
0.0043\end{array}$ & $\begin{array}{l}0.000 \\
0.000\end{array}$ \\
\hline $\begin{array}{l}\text { SiO2 } \\
\text { Si }\end{array}$ & $\begin{array}{l}69.1 \\
32.3\end{array}$ & $\begin{array}{l}68.6 \\
32.1\end{array}$ & $\begin{array}{l}68.4 \\
32.0\end{array}$ & $\begin{array}{l}68.8 \\
32.2\end{array}$ & $\begin{array}{l}68.7 \\
32.2\end{array}$ & $\begin{array}{l}0.239 \\
0.129\end{array}$ \\
\hline $\begin{array}{l}\mathrm{TiO2} \\
\mathrm{Ti}\end{array}$ & $\begin{array}{l}0.0028 \\
0.0017\end{array}$ & $\begin{array}{l}0.0030 \\
0.0018\end{array}$ & $\begin{array}{l}0.0030 \\
0.0018\end{array}$ & $\begin{array}{l}0.0030 \\
0 . r^{8} .8\end{array}$ & $\begin{array}{l}0.0030 \\
0.0018\end{array}$ & $\begin{array}{l}0.000 \\
0.000\end{array}$ \\
\hline $\begin{array}{l}3502 \\
25\end{array}$ & $\begin{array}{l}1.24 \\
0.92\end{array}$ & $\begin{array}{l}1.24 \\
0.92\end{array}$ & $\begin{array}{l}1.26 \\
0.93\end{array}$ & $\begin{array}{l}1.27 \\
0.94\end{array}$ & $\begin{array}{l}1.25 \\
0.93\end{array}$ & $\begin{array}{l}0.015 \\
0.010\end{array}$ \\
\hline
\end{tabular}

rotal oxide 99.4 ?

Dis 1 and Dis 2 - Dissolution 1 and 2 (read)

Day ind Day 2 - 1 st and 2 nd Analysis (read) 

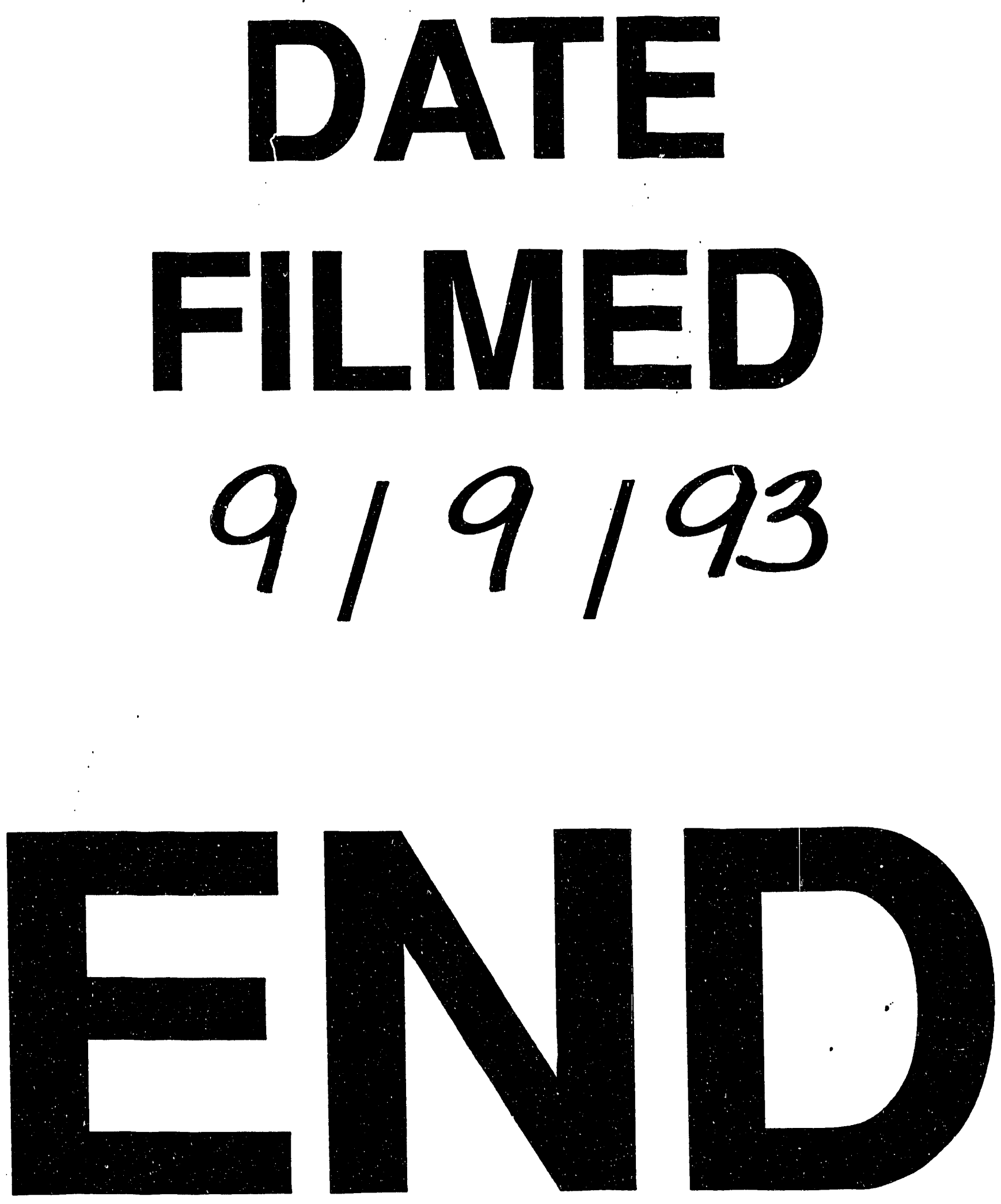
